\title{
ANTIOXIDANT SYSTEM OF RAPANS UNDER THE ACTION OF COPPER IONS AND ANIONIC DETERGENT
}

\author{
Oksana ERSHOVA *, Valentin TOPTIKOV*, \\ Tatyana LAVRENYUK *, Oleg KOVTUN * and Vladlen TOTSKY *
}

* Odessa National Mechnikov University, Dvoryanskaya Street 2, Odessa Ukraine, UA-65082, ershova@mail.ru,v.a.toptikov@gmail.com,v.totsky@onu.edu.ua

DOI: 10.1515/trser-2018-0004

KEYWORDS: Rapana venosa, antioxidant system, copper, anionic detergent.

\section{ABSTRACT}

The antioxidant system in various organs of rapana (Rapana venosa) has been studied in condition of contamination of medium with copper ions (5 and $10 \mathrm{MPC}$ ) and sodium dodecyl sulphate (5 and 20 MPC). The most significant changes in the antioxidant status of cells occurred mainly during the first hours (three-24 hours) of exposure to toxic compounds. At the end of observations (72 hours) stabilization of the main parameters of the antioxidant system and return of its main indicators to control values were noted. Ktenidiy proved to be the most sensitive organ reacting to toxic doses of both copper and sodium dodecyl sulphate in the medium. Nephridiy cells turned out to be weakly susceptible to the action of the studied toxicants. The high lability and power of the antioxidant system of rapans provides a significant adaptive potential for the mollusk.

RÉSUMÉ: Le système antioxydant des rapana veinés sous l'action des ions de cuivre et des détergents anioniques.

Le système antioxydant des différents organes des rapana veinés (Rapana venosa) a été étudié dans des conditions de contamination du milieu avec des ions de cuivre (5 et 10 MPC) et avec du lauryl sulphate de sodium (5 et 20 MPC). Les changements les plus importants dans le statut antioxydant des cellules a eu lieu durant les premières heures (trois-24 heures) d'exposition aux contaminants. A la fin des observations (72 heures) a été notée la stabilisation des principaux paramètres du système antioxydant et le retour des principaux indicateurs aux valeurs de contrôle. Les ctenidies ont été les organes les plus sensibles réagissant autant au cuivre qu'au lauryl sulphate de sodium dans le milieu. Les cellules des néphridies ont été peu sensible face à l'action des toxiques étudiés. L'étude a conclu sur l'efficacité du système antioxydant des rapana veinés, prouvant un potentiel adaptatif significatif de ce mollusque.

REZUMAT: Sistemul antioxidativ la Rapana sub acțiunea ionilor de cupru și a detergenților anionici.

Sistemul antioxidativ al diferitelor organe ale rapanei (Rapana venosa) a fost studiat în condiții de contaminare a mediului cu ioni de cupru (5 și 10 MPC) și sodiu dodecil sulfat (5 și 20 MPC). Cele mai semnificative modificări în starea antioxidativă a celulelor au avut loc în special, în timpul primelor ore (trei-24 ore) de expunere la compușii toxici. La finalul perioadei de observație (72 ore) s-au notat stabilizarea principalilor parametri ai sistemului antioxidant și revenirea principalilor indicatori la valorile de control. Cele mai sensibile organe s-au dovedit a fi ctenidiile, care au reacționat atât la cupru cât și la sodiu dodecil sulfat la concentrații toxice în mediu. Celulele nefridiilor s-au dovedit a fi destul de slab susceptibile la acțiunea toxicelor studiate. Sistemul antioxidant al rapanei este foarte flexibil, ceea ce dovedește un potențial adaptativ semnificativ al acestei moluște. 


\section{INTRODUCTION}

In recent decades, chemical pollution of the world's oceans has turned into a powerful and constantly acting factor on the marine biota (Sindermann, 1996; Khoshnood, 2017). Along with such widespread and well-studied pollutants as heavy metals; detergents (cleaning agents) are constantly being introduced to the coastal zone of the sea, and constantly present in insufficiently purified domestic sewage (Tyurin, 1994; Grousset et al., 1995; Smirnova et al., 2008). Both can have a negative impact on water quality, self-cleaning ability of water bodies, the human body, as well as potentiate effect of other pollutants (Khristoforova, 1989; Braginsky, 2003). Polluting agents lead not only to environmental deterioration, but also to the reduction of biological diversity (Khristoforova, 1989; Golovina, 2008).

It is known that hydrobionts need heavy metals as microelements for normal physiological activity (Avtsyn, 1987; Saenko, 1993). However, many metals are not transformed and, getting into the body of hydrobionts in excess, are accumulated in it. As a result, in the body of marine inhabitants there is a disruption of cellular metabolism, structure and permeability of cell membranes, increased peroxide oxidation of lipids and inhibition of oxidative phosphorylation (Golovina, 2008). Copper ranks second in toxicity after mercury, of the ten elements ( $\mathrm{Pb}, \mathrm{Cu}, \mathrm{Hg}, \mathrm{Cd}, \mathrm{As}, \mathrm{Te}, \mathrm{Zn}, \mathrm{Sn}, \mathrm{Mn}, \mathrm{Ni})$, survival effect of which were tested in mussel and oyster embryos (Tamoznya and Goromosova, 1985). Excess concentration of copper ions in sea water has a significant effect on the physiological and biochemical status of fish and marine invertebrates, it inhibits growth of larvae of the Pacific mussel Mytilus trossulus (Yaroslavtseva and Sergeeva, 2005; Golovina, 2008). Ecological hazard of detergents is significantly less studied than that of pesticides, heavy metals and other toxicants. There are data that detergents led to inhibition of the filtration activity of freshwater mollusks, mussels and oysters, changed behaviour of the medicinal leech, suppressed activity of some enzymes in the gills of fish (Ostroumov et al., 1997). Surfactants in concentration of $0.50-$ $0.25 \mathrm{mg} / \mathrm{l}$ cause death of crustaceans and fish, their lower concentrations inhibit growth and development of hydrobionts, impair absorption of food, inhibit chemoreceptor function, sublethal concentrations of detergents disrupt mobility of sex cells and sporulation in algae (Miseiko et al., 2001). When detergent concentrations reach one $\mathrm{mg} / \mathrm{l}$, plankton perish, at three $\mathrm{mg} / \mathrm{l}$ daphnia perish, at $15 \mathrm{mg} / \mathrm{l}$ fish perish (Bogolyubova, 1997).

It is known that the antioxidant system is the first to react to environmental changes. Previously, we studied antioxidant system activity of gastropod Rapana venosa from various areas of the Black Sea with different contamination levels (Totsky et al., 2013). However, we did not study specific effects of individual pollutants on the shellfish organism. That said, the purpose of this study was to observe the reaction of antioxidant system of rapana to copper and anionic detergent in concentrations exceeding the limit.

\section{MATERIAL AND METHODS}

In the research we used sexually mature individuals of rapanas collected in the coastal water area of the Odessa Gulf in the summer of 2015. Mollusks were acclimatized to laboratory conditions for a week in several aerated aquariums with sea water taken from the area where the animals were caught. Each 200-liter aquarium contained 20-22 animals. The water in the aquariums was changed every second days. 
After acclimation of the experimental group, the test compound was added to the water. When choosing experimental concentrations of the test substances we relied on the data presented in the work of Zaitsev et al. (2006). We used the following doses of the compounds: 1) copper sulphate at the concentration of $5 \mathrm{MPC}(25 \mu \mathrm{g} / 1$ in terms of the copper ion), 2) copper sulphate at a concentration of $10 \mathrm{MPC}$, 3) sodium dodecyl sulphate (anionic detergent of many cleaning agents) at the concentration of 5 MPC $500 \mu \mathrm{g} / 1,4)$ sodium dodecyl sulphate at the concentration of 20 MPC. It is known that in aqueous media, copper cations, reacting with metabolic by-products of organisms, quickly shift into bound insoluble state (Dyatlov et al., 2012). In this regard, copper sulphate was repeatedly introduced into the medium up to the required MPC value on the second day of the experiment. In the control group, the mollusks were kept in ordinary seawater.

After three, 24 and 72 hours, sic-eight individuals of each group (control and experimental) were selected for analysis. At the end of the experiment, the rapanas were stored in a freezer at $-18^{\circ} \mathrm{C}$.

For biochemical analysis we used ktenidiy, hepatopancreas and nephridiy of the mollusk. Homogenates were prepared according to the generally accepted method (Prokhorova, 1982). To prepare homogenates we combined tissues of several individuals of both sexes in equal proportions. The total antioxidant activity (TAA) was determined in the obtained samples according to inhibition degree of ascorbate- and ferroinduced oxidation of tvine-85 up to MDA (Goryachkovsky, 1998), content of malonic dialdehyde (MDA) (Stalnaya and Garishvili, 1977) and reduced glutathione (GSH) (Goryachkovsky, 1998).

The obtained data were calculated per gram of wet weight of the tissue. In this study, the results obtained for experimental animals are presented on percentage base with reference to the corresponding control values. Control was taken as $100 \%$. The diagrams show the arithmetic mean of the values and their standard error. Statistical processing of the results was carried out using the application Microsoft Office Excel. The reliability of differences in the tested parameters was determined using Student's t-test for conjugate populations.

\section{RESULTS AND DISCUSSION}

Addition of either copper ions or sodium dodecyl sulphate to the environment did not lead to a change in the general activity of mollusks during the period under investigation and did not have lethal effect. This suggests that the revealed antioxidant system changes will reflect the adaptation process of mollusks to unfavourable conditions.

The choice of organs for investigation is determined by their physiological functions. Ktenidiy, as an organ, is the first to face polluted environment, and its work induce how the organism will be provided with oxygen. The role of nephridiy is determined by its excretory function, and one of the important tasks of hepatopancreas is neutralization of toxic compounds that get inside and are formed in the process of metabolism (Chukhchin, 1970).

One of the end products of the lipid peroxidation destructive effects is MDA. The level of this compound reflects the state of dynamic equilibrium between oxidants and antioxidants and gives a general idea about the state of the body's antioxidant defence system. The effects of copper and anionic detergent on the content of MDA in different organs of rapana are shown in figures 1 and 2. In control samples the content of dialdehyde in ktenidiy, depending on the variant of the experiment, ranged from $16.7 \pm 1.7$ to $24.2 \pm 1.3 \mathrm{nmol} / \mathrm{g}$ of tissue, in hepatopancreas - from $21.8 \pm 2.6$ to $31.9 \pm 2.5 \mathrm{nmol} / \mathrm{g}$ tissue, in nephridiy - from $15.4 \pm 2.9$ to $33.7 \pm 1.6 \mathrm{nmol} / \mathrm{g}$ tissue. 
Copper ions at a concentration of 5 MPC in the medium did not have a significant effect on the content of dialdehyde in all the tested organs of rapana throughout the entire observation period. An increase in the copper dose up to 10 MPC led to an increase of lipid peroxidation in some organs. Moreover, an increase of dialdehyde concentration in hepatopancreas was observed in all periods of exposure compared to the control, whereas in ktenidiy it was observed only at the beginning (three and 24 hours) of rapanas' dwelling in water containing copper sulphate. On the third day, the amount of MDA in ktenidiy returned to the control level. It suggests that the observed temporary increase in the level of dialdehyde in ktenidiy is not associated with destructive processes in this organ, but with the reorganization of membranes necessary for adjustment of this organ to new conditions (Los, 2001; Ozernyuk, 2003). The tissues of nephridiy of rapana proved to be the most resistant to the effect of copper toxic doses: in individuals of the experimental group MDA content did not differ significantly from the control during the entire observation period and at different concentrations of $\mathrm{Cu}^{2+}$ (Fig. 1).

a)

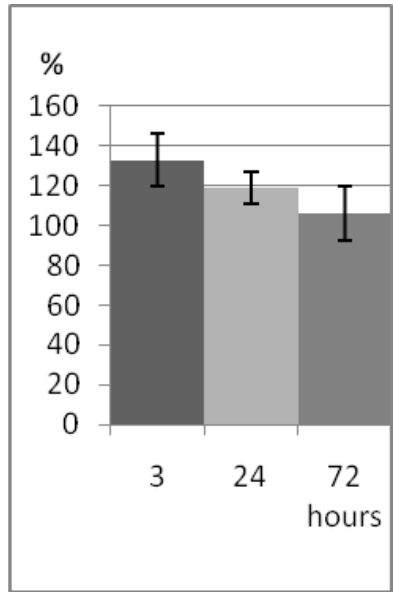

b)

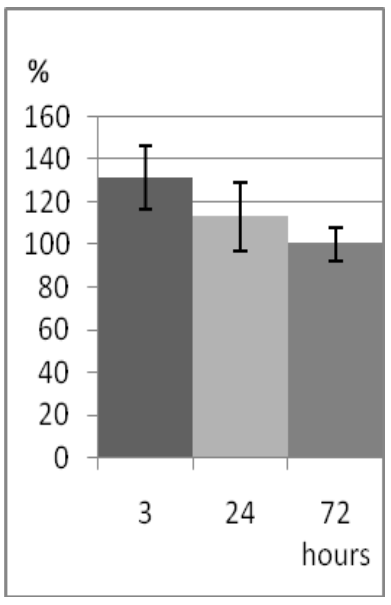

c)
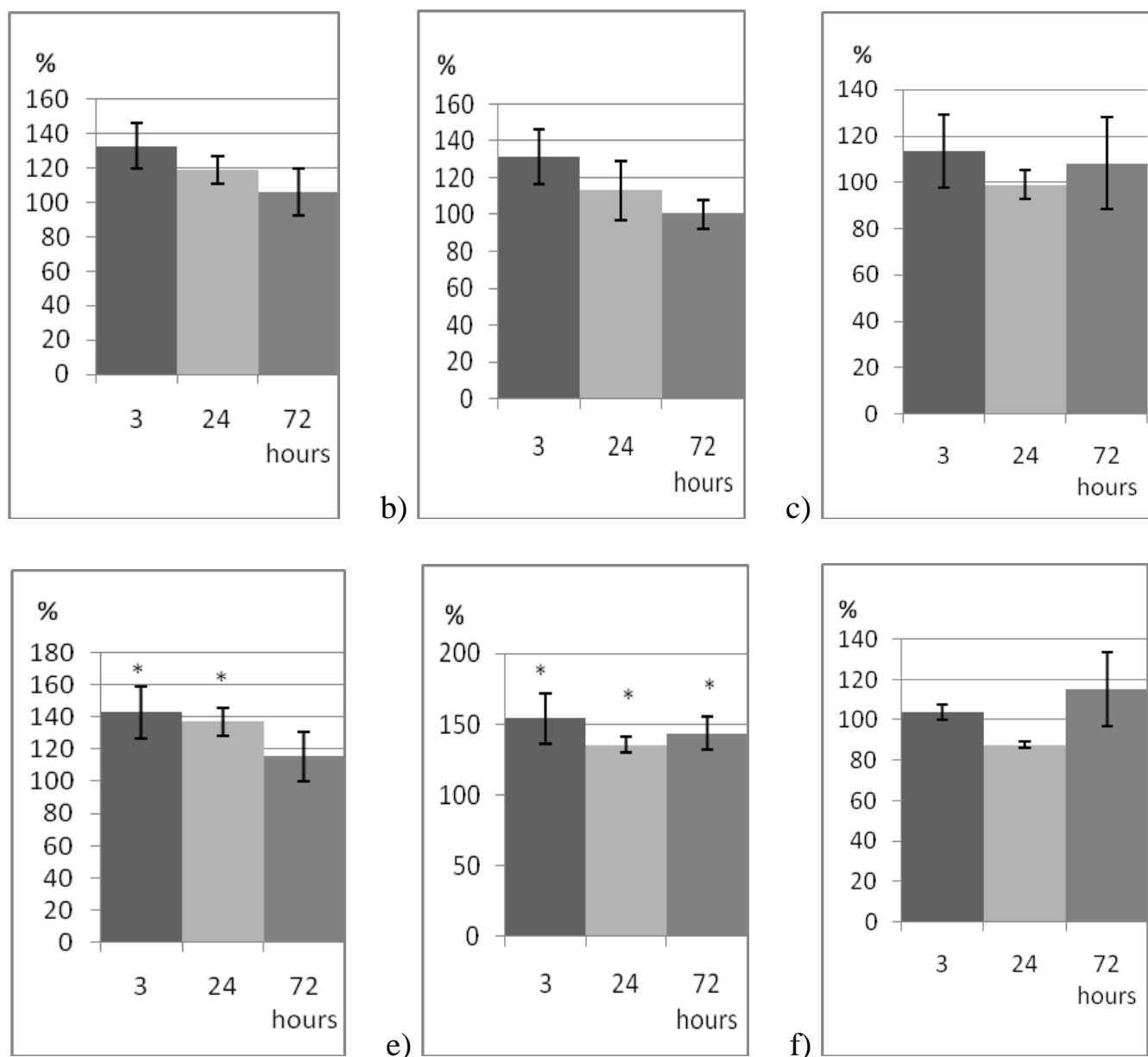

e)

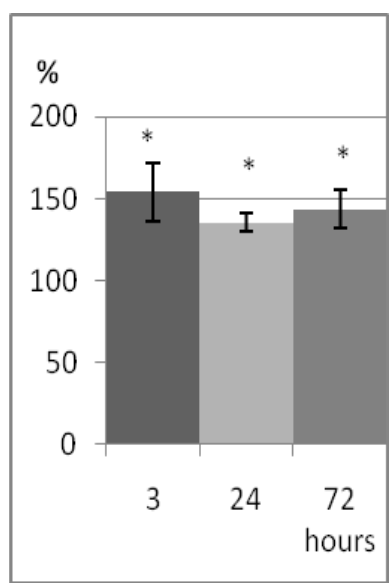

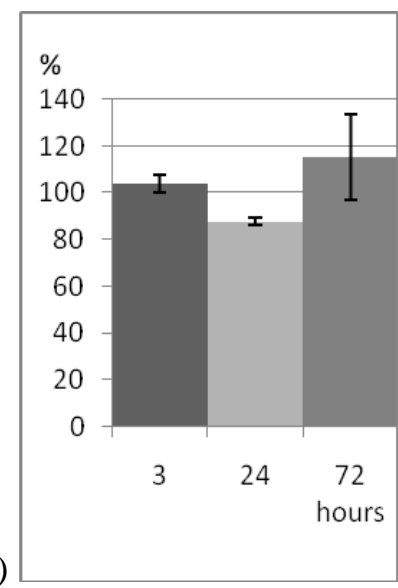

f)

Figure 1: Dynamics of the content of MDA in ktenidiy (a, d), hepatopancreas (b, e) and nephridiy (c, f) rapans in the presence of copper ions; $\mathrm{a}-\mathrm{c}-5 \mathrm{MPC} \mathrm{Cu}{ }^{2+}$, d-f - $10 \mathrm{MPC} \mathrm{Cu}^{2+}$;

$*$ - significant difference from control at $\mathrm{P}<0.05$; the control values were taken as $100 \%$. 
Anionic detergent did not enhance lipid peroxidation in the cells of hepatopancreas and nephridiy of rapana (Fig. 2). More susceptible to the effect of this xenobiotic was ktenidiy. On the third day of exposure, the MDA level in the ktenidiy exceeded the control values by one and a half times which may indicate a significant damage to the detergent of the cell membranes of the ktenidiy (Fig. 2).
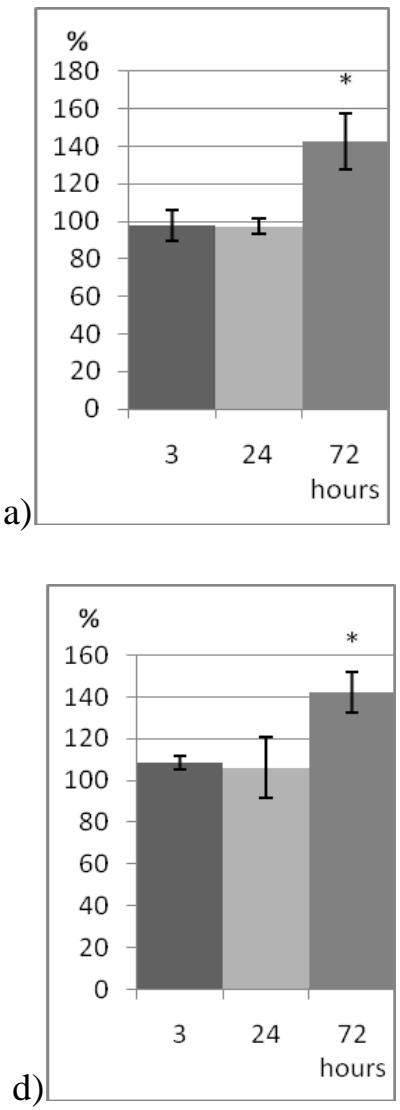

b)
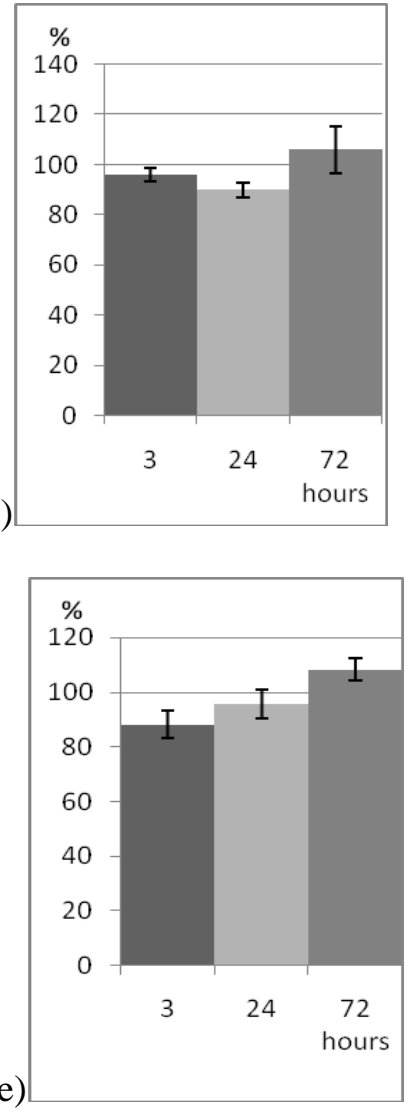
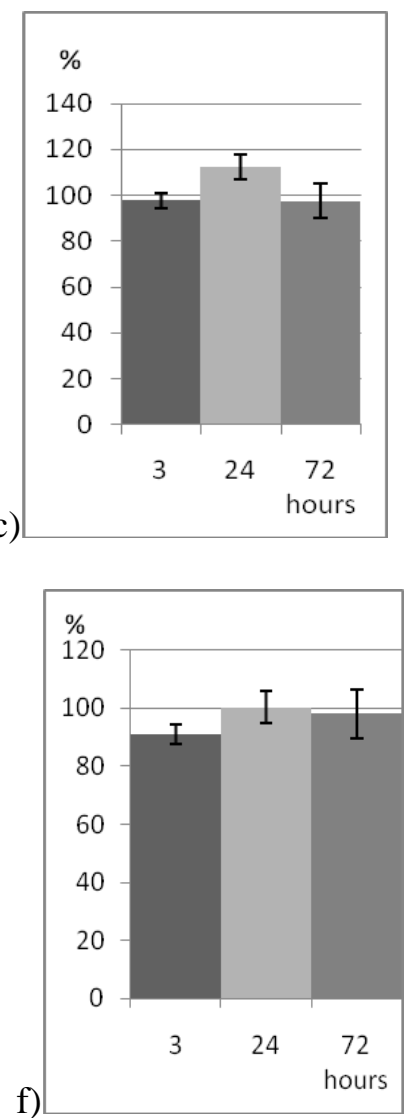

Figure 2: Dynamics of MDA content in ktenidiy (a, d), hepatopancreas (b, e) and nephridiy

(c, f) rapans in the presence of sodium dodecyl sulphate; a-c - 5 MPC, d-f - 20 MPC;

$*$ - significant difference from control at $\mathrm{P}<0.05$; the control values were taken as $100 \%$.

Glutathione reduced (GSH) is one of the most important non-enzymatic components of the antioxidant system. It exhibits both direct antioxidant activity and functions as a hydrogen donor for enzymes of the antioxidant system and supports the sulfhydryl groups of functionally important proteins in the reduced state (Kenya et al., 1993). In this regard, the definition of this component is important for assessing the state of the antioxidant system. The content of GSH, depending on the variants of the experiment in the ktenidiy control groups, was in the range $0.36 \pm 0.03$ to $0.62 \pm 0.06 \mathrm{nmol} / \mathrm{g}$ tissue, in hepatopancreas from $0.40 \pm 0.05$ to $1.20 \pm 0.35$ $\mathrm{nmol} / \mathrm{g}$ tissue, in nephridiy from $0.22 \pm 0.03$ to $0.36 \pm 0.03 \mathrm{nmol} / \mathrm{g}$ tissue. 
Determination of the level of GSH in the studied tissues of rapana showed that the most stable in this indicator were nephridiy cells. In the presence of toxic concentrations of copper, the amount of antioxidant in this organ did not differ from the control, and on the third day of the detergent's effect it even increased by one and a half times in comparison with the control values (Figs. 3 and 4).

The paradoxical response of the antioxidant system to toxicants was observed in the tissues of the ktenidiy and hepatopancreas (Fig. 3). Thus, a significant decrease in the amount of glutathione in the ktenidiy occurred only at a $\mathrm{Cu}^{2+}$ concentration in the mollusk habitat of 5 MPC. A higher dose of the toxicant did not have a significant effect. Similarly, in hepatopancreas at higher copper concentrations, the change occurred later and to a lesser extent: five times the maximum concentration of copper caused a decrease in the level of GSH by three times after three hours of exposure, 10 times the MPC twice a day. After the decrease in the amount of reduced glutathione observed in the tissues of the ktenidiy and hepatopancreas at the end of the exposure, there was no significant effect of copper. This may be due either to the activation of glutathione reductase restoring oxidized glutathione, or to the stimulation of the synthesis of this antioxidant due to other adaptation mechanisms.

The presence of sodium dodecyl sulphate in the medium did not significantly affect the content of reduced glutathione in hepatopancreas cells, whereas in the ktenidiy both concentrations of detergent caused a significant increase in the amount of GSH from the very beginning of the observations (Fig. 4).

a)
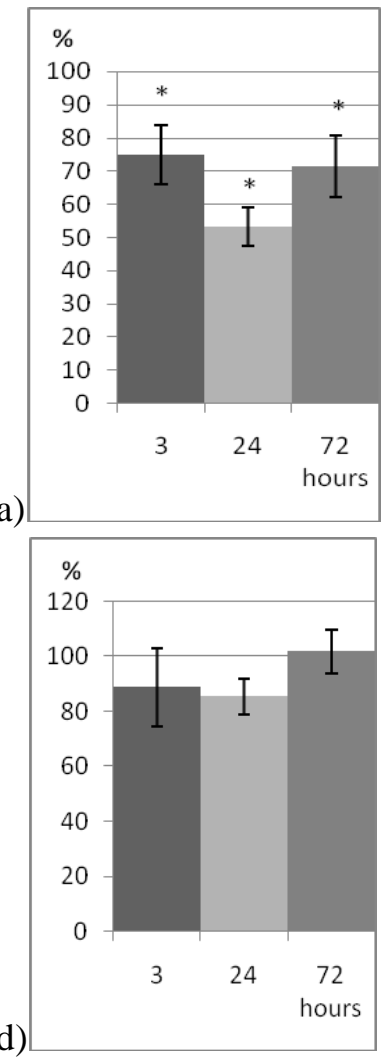

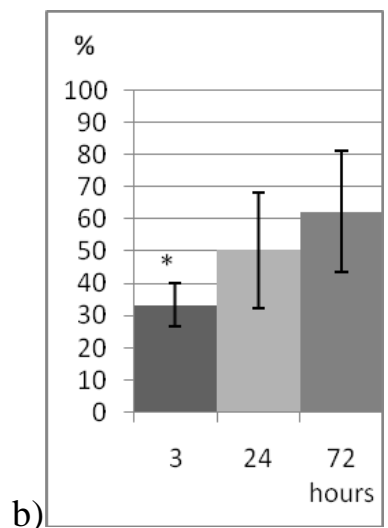

b)

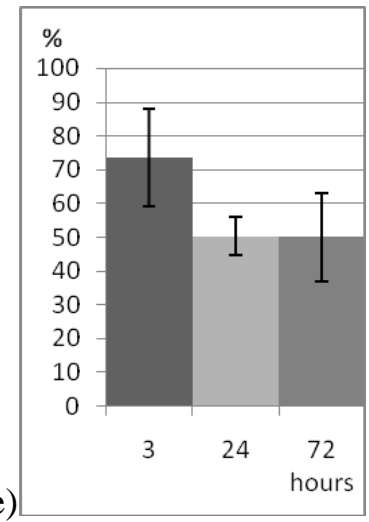

c)
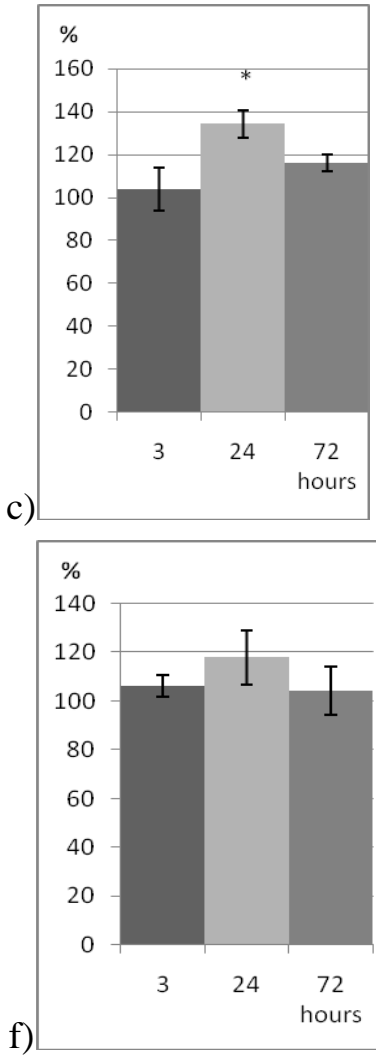

Figure 3: Dynamics of the content of reduced glutathione in ktenidiy (a, d), hepatopancreas (b, e) and nephridiy (c, f) in the presence of copper ions; a-c - $5 \mathrm{MPC} \mathrm{Cu}^{2+}$, d-f - $10 \mathrm{MPC} \mathrm{Cu}^{2+}$; * - significant difference from control at $\mathrm{P}<0.05$; the control values were taken as $100 \%$. 

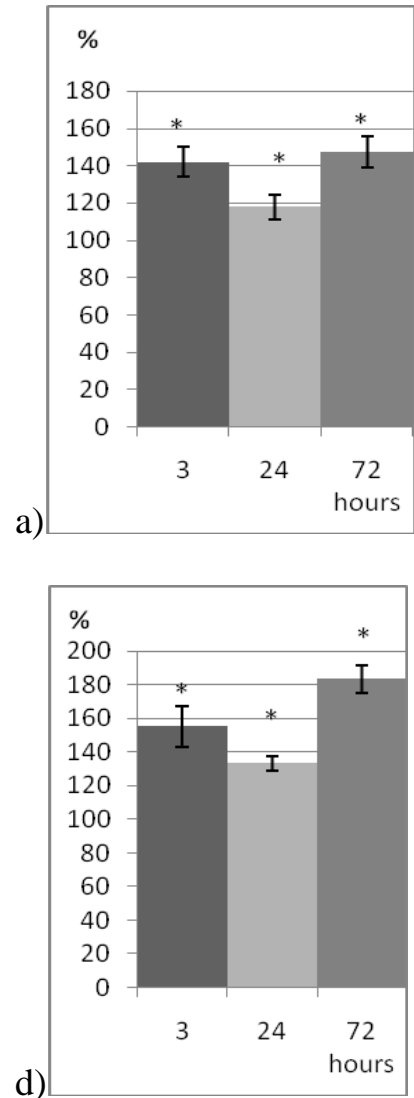

b)
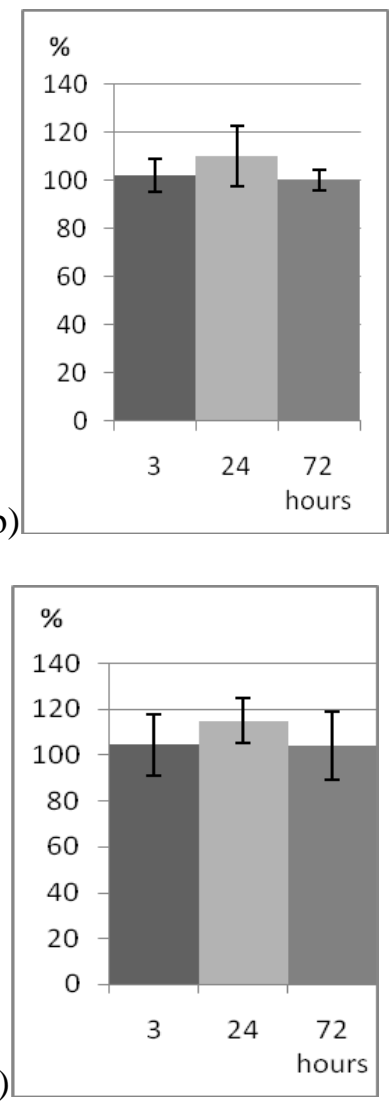

c)
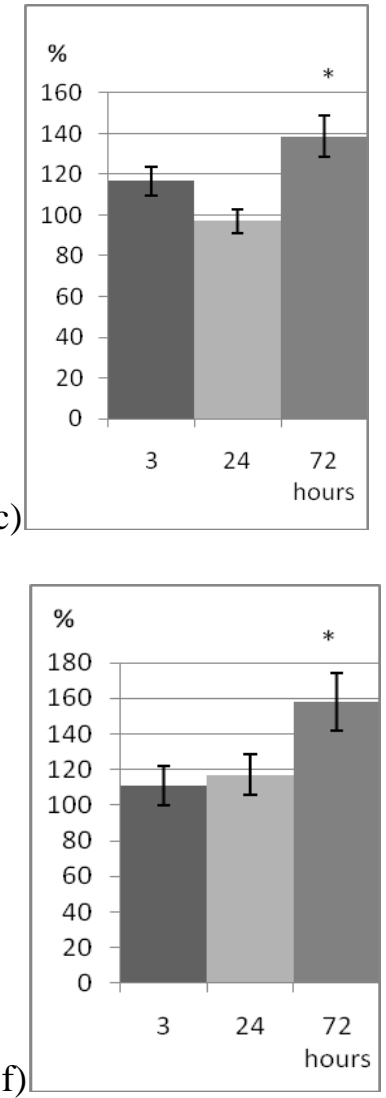

Figure 4: Dynamics of the content of reduced glutathione in ktenidiy (a, d), hepatopancreas (b, e) and nephridiy (c, f) rapans in the presence of sodium dodecyl sulphate; a-c -5 MPC, d-f-20 MPC; * - significant difference from control at $\mathrm{P}<0.05$; the control values were taken as $100 \%$.

One more integral indicator was used to determine the state of the antioxidant system, which reflects the body's ability to counteract the development of free radical reactions - total antioxidant activity (TAA). The investigated doses of copper ions did not lead during the entire period of observations to significant changes in TAA in nephridiy and hepatopancreas of experimental mollusks in comparison with control ones. In ktenidiy there was a temporary weakening of the overall antiradical protection of cells by three hours of exposure at the maximum used concentration of this toxicant (10 MPC). But within a day the given indicator returned to the norm (Fig. 5d).

Similarly, the detergent also influenced the cells of the ktenidiy: after a decrease in the level of TAA to three hours of aging of the rapana in a medium with xenobiotic, after 24 hours its recovery to control values was noted (Figs. 6a, d). Unlike copper, sodium dodecyl sulphate exerted a marked effect on the state of the overall antioxidant activity in nephridiy and hepatopancreas, which manifested itself at the end of the aging of the rapana in a detergent medium (Figs. 6b, e, f). 
a)

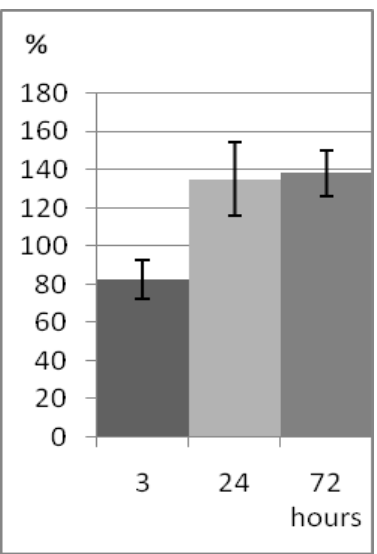

b)
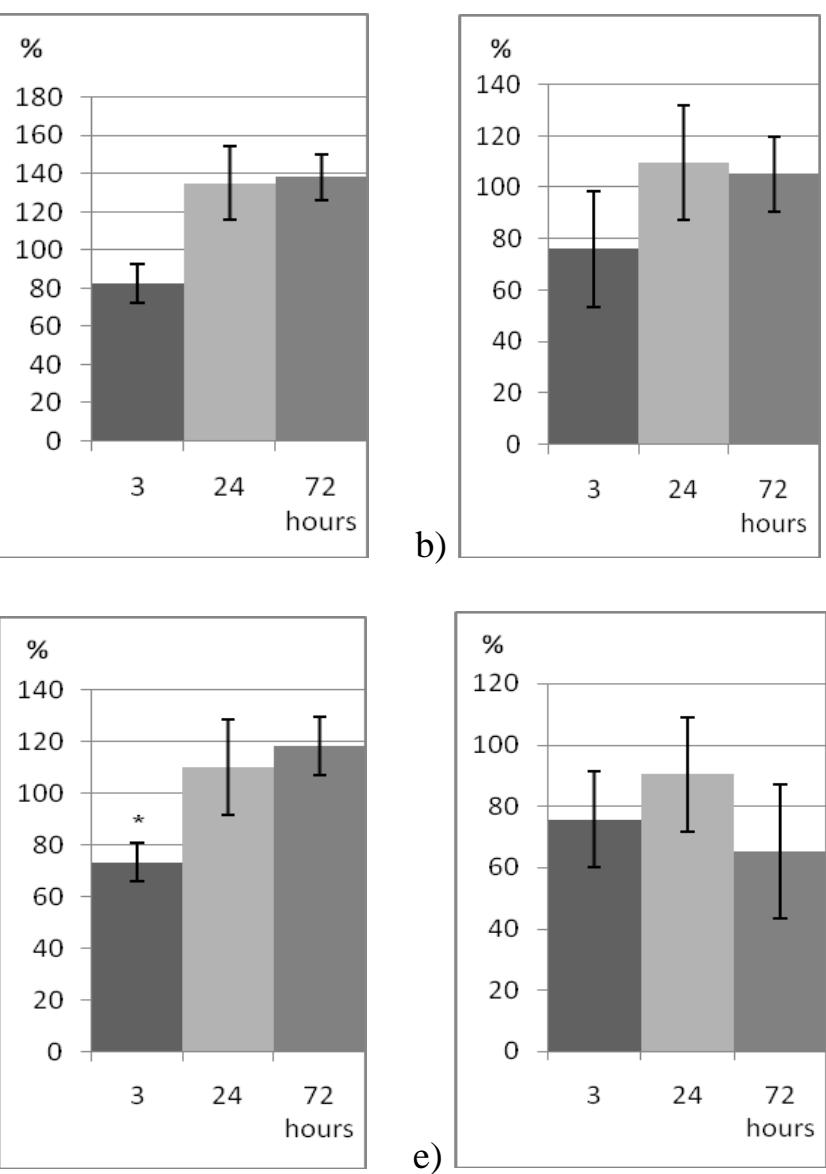

e)

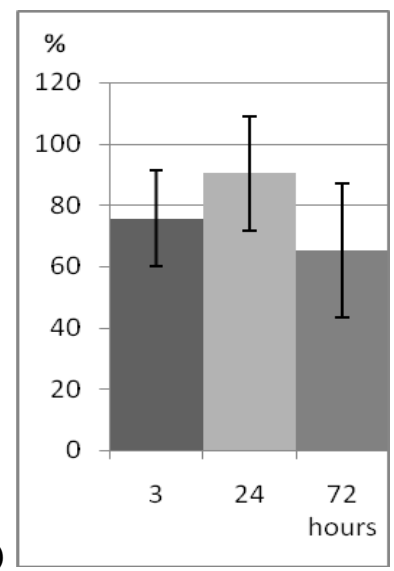

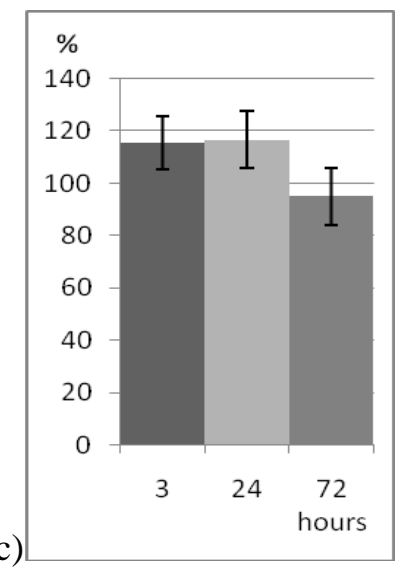

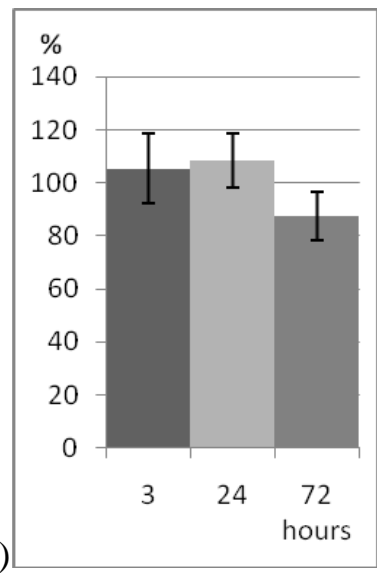

Figure 5: Dynamics of total antioxidant activity in ktenidiy (a, d), hepatopancreas (b, e) and nephridiy (c, f) in the presence of copper ions; a-c - $5 \mathrm{MPC} \mathrm{Cu}^{2+}$, d-f - $10 \mathrm{MPC} \mathrm{Cu}^{2+}$; $*$ - significant difference from control at $\mathrm{P}<0.05$; the control values were taken as $100 \%$. 
a)
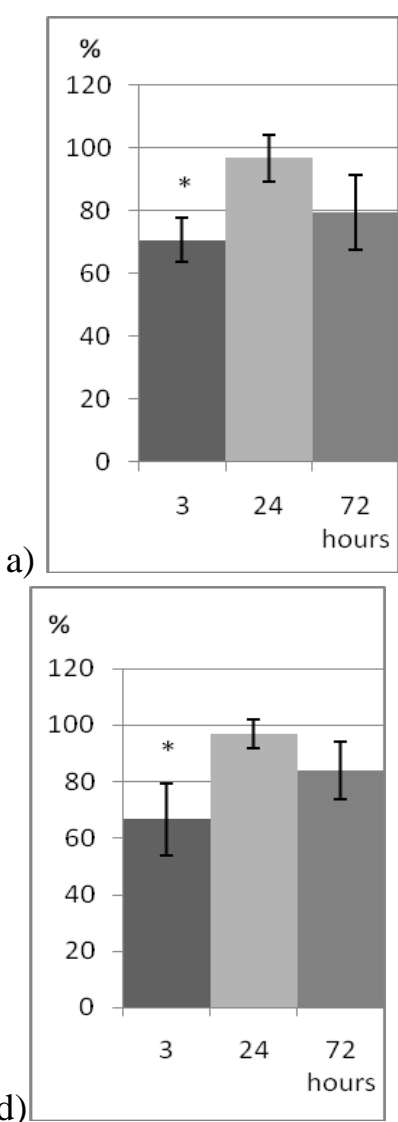

b)
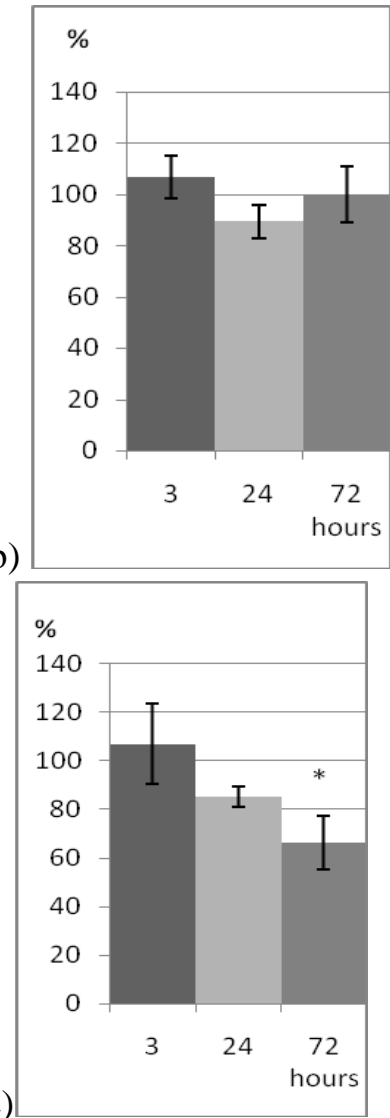

c)

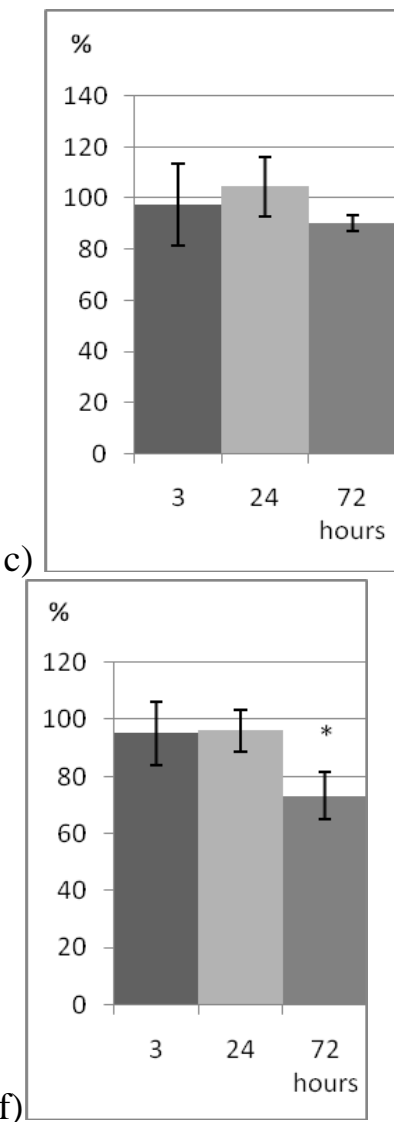

Figure 6: Dynamics of total antioxidant activity in ktenidiy (a, d), hepatopancreas (b, e) and nephridiy ( $c, f$ ) rapans in the presence of sodium dodecyl sulphate;

a-c - 5 MPC; d-f - 20 MPC; * - significant difference from control at $\mathrm{P}<0.05$; the control values were taken as $100 \%$.

It is possible to make some assumptions about the possible mechanisms of the reaction of the antioxidant system of rapana in response to the effects of the toxicants under study comparing the direction of changes in the studied indicators. It is likely that the reduced glutathione plays a leading role in the formation of antioxidant protection of rapans, as changes in its concentration in cells are associated with changes in the level of TAA and the content of dialdehyde. Thus, a decrease in the total antioxidant activity in the ktenidiy in a medium with a detergent (Figs. 6a, d) and an increase in the amount of MDA in the ktenidiy by three hours of exposure (Figs. 2a, d) was accompanied by an increase in the concentration of glutathione in the tissues of the organ, followed by normalization of the general state of the antioxidant system (Figs. 4a, d). The drop in the level of TAA in nephridiy (Fig. 6f) in the presence of sodium dodecyl sulphate is associated with an increase in the content of GSH in its tissues (Fig. 4c). Also in the hepatopancreas of a mollusk on media with copper ions, an increase in the content of dialdehyde in the first hours of exposure (Fig. 1b) is associated with a subsequent increase in the concentration of glutathione in cells (Fig. 3b). 
Diverse organs of the mollusc react to the environment pollution in a different way. Ktenidiy is the most sensitive organ that reacts to the presence of toxic doses in the environment, both copper and sodium dodecyl sulphate (Figs. 1d, 2a, d, 3a, 4a, d, 5d). This fact can be interpreted by the fact that the cells of this organ come first into contact with the habitat and its elements. The cells of nephridiy did not react to the presence in the medium of increased doses of copper, but were more sensible to the detergent (Figs. 4c, f, 6f). In hepatopancreas cells, the presence of copper in the environment led to enhanced lipid oxidation (Fig. 1e), which was neutralized by a relative increase in the level of reduced glutathione and stabilization of the level of total antioxidant activity (= antiradical ability).

\section{CONCLUSIONS}

Despite the pollution of the aquatic environment, the species $R$. venosa is rapidly advancing in various areas of the World Ocean. Successful settlement of this mollusk is associated with its high plasticity, undemanding to the physicochemical conditions of the environment and food sources, a number of general biological features, ontogenetic in particular.

As our studies show, the wide adaptive capabilities of rapana are also determined by the properties of its antioxidant system. It is shown that the reaction of the antioxidant system of rapans in response to unfavourable environmental conditions (high content of copper ions and anionic detergent) occurs already in the first hours of exposure. However, after 24 hours, the state of the antioxidant protection system of the mollusk is relatively stabilized and many of its indices return to normal. This indicates a significant capacity and lability of antioxidant mechanisms of rapans. The results obtained are additional evidence of numerous observations on the high ductility and adaptability of $R$. venosa.

\section{ACKNOWLEDGEMENTS}

The authors thanks to the head of department of water quality, Senior Researcher Institute of marine biology of NASU, Mr. Dyatlov for consultation in the planning of the experiment. 


\section{REFERENCES}

1. Avtsyn A. P., 1987 - Human microelementoses, Clinical medicine, T. 65, 6, 36-44. (in Russian)

2. Bogolyubov S. A., 1997 - Ecology, Textbook, Knowledge, 288. (in Russian)

3. Braginsky L. P., 2003 - Comprehensive analysis of the toxicological hazard of surfactants for hydrobionts, Hydrobiological Journal, 39, 3, 115-118. (in Russian)

4. Chukhchin V. D., 1970 - Functional morphology of rapana, Naukova Dumka, 138. (in Russian)

5. Dyatlov S. E., Chepizhko O. V. and Urdya V. A., 2012 - Interannual variability of heavy metals in water and sediments landfill "Odessa region NWBS" Ecological safety of coastal and shelf zones and complex use of shelf resources, 26, V.1., S. 257-268. (in Ukrainean)

6. Golovina I. L., 2008 - The influence of heavy metals on the physiological and biochemical status of fish and aquatic invertebrates, Biology of inland waters, 1, 99-108. (in Russian)

7. Goryachkovsky A. M., 1998 - Clinical Biochemistry, 2nd edition, Astroprint, 608. (in Ukrainean)

8. Grousset F. E., Quetel C. R. and Thomas B., 1995 - Anthropogenic vs. lithogenic origins of trace elements (As, Cd, Pb, Rb, Sb, Sn, $\mathrm{Zn}$ ) in water column particles: Northwestern Mediterranean Sea, Marine Chemistry, 48, 3-4, 291-310.

9. Kenya M. V., Lukash A. I. and Guskov E. P., 1993 - The role of low-molecular antioxidants in oxidative stress, Successes of the modern Biology, 113, 4, 456-470. (in Russian)

10. Khoshnood Z., 2017 - Effects of environmental pollution on fish: a short review, Transylvanian Review of Systematical and Ecological Research, 19.1, The Wetlands Diversity, 49-60.

11. Khristoforova N. K., 1989 - Bioindication and monitoring of pollution of sea water by heavy metals, Far East Branch of the Academy of Sciences of the USSR, Science, 192. (in Russian)

12. Los D. A., 2001 - Structure, regulation of experiment and functioning of desaturates of fatty acids, Uspekhi biology, Chemistry, 41, 163-198. (in Russian)

13. Miseiko G. N., Bezmaternykh D. M. and Tushkova G. I., 2001 - Biological analysis of the quality of fresh water, Barnaul AGU, 201. (in Russian)

14. Mitropolskiy A. Y., Nasedkina E. I. and Osokina N. P., 2006 - Ekoheohimiya Black Sea, Academperiodica, 278. (in Ukrainean)

15. Ostroumov S. A., Donkin P. and Staff F., 1997 - Inhibition by the anionic surfactant of the ability of Mytilus edulis mussels to filter and purify seawater, Vestnik Moscow University, 16, Biology, 2, 30-35. (in Russian)

16. Ozernyuk N. D., 2003 - Phenomenology and mechanisms of adaptation processes, Moscow, MSUU, 215. (in Russian)

17. Prokhorova M. I., 1982 - Methods of biochemical research (lipid and energy metabolism), Leningrad, Leningrad University, 271. (in Russian)

18. Saenko G. N., 1993 - Metals and halogens in marine organisms, Science, 252. (in Russian)

19. Sindermann C. J., 1996 - Ocean Pollution: Effects on Living resources and Humans, CRC Press, Boca Raton, FL, ISBN 0-8493-8421-4, 262.

20. Smirnova L. L., Andreeva N. A. and Saltykova L. V., 2008 - Microelement composition and microflora of the atmospheric suspension of the seaside of the city of Sevastopol (Black Sea), Urban ecology and recreational areas: Material All-Ukrainian scientific and practical conference April 17-18, Odessa, 208-211. (in Russian)

21. Stalnaya D. I. and Garishvili T. G., 1977 - Method for the determination of malonic dialdehyde with thiobarbituric acid/Cb. Modern methods in biochemistry, Moscow, 66-68. (in Russian)

22. Tamoznya V. A. and Goromosova S. A., 1985 - Biochemical indices of metabolism of mussels during the action of toxins on them, Ecology of the Sea, 16, 64-68. (in Russian)

23. Totsky V. N., Ershova O. N., Toptikov V. A., Kovtun O. A., Dragoeva A. G. and Lavrenyuk T. I., 2013 - The state of the antioxidant system in representatives of Rapana venosa (Valenciennes, 1846), inhabiting different waters of the Odessa Bay (Black Sea), Vestnik ONU, Biologiya, 18, 1, 30, 7-19. (in Russian) 
24. Tyurin A. N., 1994 - Action of metal ions and detergents on the development of chitons, Author's abstract, Vladivostok. (in Russian)

25. Yaroslavtseva L. M. and Sergeeva E. P., 2005 - Influence of copper ions on the early stages of development of the Pacific mussel Mytilus trossulus, Institute of Marine Biology, Far East Branch, Russian Academy of Sciences, Marine Biology, 31, 4, 267-273. (in Russian)

26. Zaitsev Y. P., Aleksandrov B. G. and Minicheva G. G., 2006 - North-Western part of the Black Sea: biology and ecology, Naukova Dumka, 701s. (in Russian) 